\title{
Is There a Difference in the Resonance Frequency Values Obtained Directly on the Implants and Abutments?
}

\author{
¿Existe Diferencia en la Frecuencia de Resonancia \\ Obtenida Directamente en los Implantes y Pilares?
}

\author{
Leandro Pozzer; Marisa Aparecida Cabrini Gabrielli*; Renato Augusto Torres Neto*; \\ Rubens Spin-Neto*; Luciana Asprino* \& Valfrido Antonio Pereira-Filho,,**
}

POZZER, L.; GABRIELLI, M. A. C.; TORRES NETO, R. A.; SPIN-NETO, R.; ASPRINO, L. \& PEREIRA-FILHO, V. A. IS there a difference in resonance frequency values obtained directly on the implants and abutments? Int. J. Odontostomat., 9(3):483-487, 2015.

ABSTRACT: The aim was to evaluate the differences of implant stability quotient (ISQ) between implants with external hexagon and Morse taper connectors. The study had a split mouth design, composed by 10 patients who received hybrid protocol prosthesis. In total, 40 implants $(3.75 \times 13 \mathrm{~mm})$ were installed: on the right side, 20 external hexagon, and on the left, 20 Morse taper. After two years in function, the stability test was applied by using the MRI machine Osstell ISQ directly on the implants and on the abutments. Considering the measurements made on the implants, there were differences between HE and CM mesial $(p=0.011)$, lingual $(p=0.003)$ and distal $(p=0.006)$. Considering the measurements made on the abutments, there were differences between HE and CM on the buccal $(p=0.020)$ and lingual $(p=0.004)$. The trend and higher values are for the CM group. The values for Morse taper implants were always higher in a statistically significant manner, when compared to the external hexagon.

KEY WORDS: Implant stability, implant stability quotient, dental implant.

\section{INTRODUCTION}

The achievement of a "functional ankylosis" (Schroeder et al., 1976), also termed "osseointegration" (Brånemark et al., 1997), provides the concept of success on implant installation. The macroscopic structure of the implant, together with the bony walls of the prepared site, provides primary stability, while secondary stability is directly related to the biological relationship between implant surface and bone tissue (Abrahamsson et al., 2004). During the osseointegration period, primary stability will be replaced by a biological bonding of newly formed bone to the implant surface and creating secondary stability. The many events which happen during the tissue integration process, such as bone remodeling at the implant- bone interface, may determine the degree of secondary implant stability (Sennerby \& Meredith, 1998).

Several techniques have been suggested for the determination of implant stability. The most common and simple (and probably most inaccurate) evaluation technique was the percussion test, carried out by tapping the handle of a dental instrument against the implant or the mounted abutment (Adell et al., 1985). Another commonly used method was the use of radiographic interpretation, to evaluate pre-operatively bone quality and quantity, in the edentulous sites (refs). Such an assessment was not really able to determine implant stability. In recent years, resonance frequency analysis (RFA) has been introduced to provide noninvasive and objective assessments of implant stability and to monitor stability over time (Meredith et al., 1996, 1997a, 1997b; Heo et al., 1998; Rasmusson et al. 1998, 1999, 2001; Friberg et al. 1999a, 1999b; Balleri et al., 2002; Bischof et al., 2004; Huwiler et al. 2007; KesslerLiechti et al., 2008; Sim \& Lang 2010).

The original electronic RFA device used a direct connection (wire) between the transducer and the

\footnotetext{
* Division of Oral and Maxillofacial Surgery, Piracicaba Dental School, State University of Campinas, Campinas, Brazil.

" Department of Diagnosis and Oral and Maxillofacial Surgery, Dental School of Araraquara, Sao Paulo State University, Araraquara, Brazil.
} 
resonance frequency analyzer. The transducer was an L-shaped cantilever beam, which was connected to the implant via a screw attachment. A piezoelectric crystal on the vertical portion of the L-shaped beam was used to stimulate the implant/transducer complex; a second piezoelectric crystal on the opposite side of the beam was used as the receiving element to detect the response of the beam. The second more recent development is a magnetic device, which uses the magnetic frequencies between the transducer (a magnetic peg) and the resonance frequency analyzer. The transducer is a metallic rod with a magnet on top that is screwed onto an implant or an abutment. The magnet is activated by a magnetic pulse of approximately 1-ms duration from a wireless probe. After excitation, the peg vibrates freely, and the magnet induces the electric voltage in the probe coil. This voltage is the measurement signal sampled by the resonance frequency analyzer. The results of an RFA are expressed as an implant stability quotient (ISQ) on a scale from 1 to 100 , which represents a standardized unit of stability. Generally, the ISQ has been found to vary between 40 and 80 for clinically stable implants (Aparicio et al., 2006).

The purpose of this clinical study was to assess implant stability quotient (ISQ) differences between implants with external hexagon and Morse taper connectors.

\section{MATERIAL AND METHOD}

This is an experimental case-series clinical study and the patients were enrolled at the Department of Oral and Maxillofacial Surgery Araraquara Dental School, São Paulo State University - UNESP, SP, Brazil, after signing a authorization term approved by the Araraquara Dental School Ethics Committee (\# 72-09).

The sample was composed by 10 patients who received hybrid protocol prosthesis in which the metallic infrastructure was merged and screwed to the abutments and the teeth were mounted over this structure. The prosthesis were immediately loaded. The study had a split mouth design and each patient received four implants. On the right side, external hexagon implants $(3.75 \times 13 \mathrm{~mm}$, NEODENT, Curitiba, Brazil) were used, while on the left Morse taper (3.75 x $13 \mathrm{~mm}$, NEODENT, Curitiba, Brazil) implants were used. In total, 40 implants were installed (20 external hexagon and 20 Morse taper). After two years in function, the prosthesis were unscrewed and stability test was applied by using the MRI machine Osstell ISQ.

Briefly, the prosthesis were unscrewed and a specific SmartPeg was attached to the implant (Type 16 and Type 1). The, it was possible to determine the ratio of the response of osseointegration SmartPegs for Osstell ISQ in each side of the implant, buccal, lingual, mesial and distal. Likewise, SmartPegs were coupled on the abutments and followed the measuring at all the faces of the implants. Thus, data were obtained with Osstel ISQ (Osstell AB, Gotenborg, Sweden) in all implants (external hexagon and Morse taper) both directly on the implants and on the abutments.

The results were subjected to statistical analysis to assess whether there was a significant difference on the rate of osseointegration between implants (external hexagon and Morse taper) and between the abutments.

\section{RESULTS}

Comparisons within the same group (HE or $\mathrm{CM}$ ) and subgroup (implant or abutments) in relation to the measurement locations (using the KruskalWallis test followed by Dunn's multiple comparison test) were not statistically significant.

Comparing $\mathrm{HE}$ and $\mathrm{CM}$ in each subgroup (implant or abutment) and according to the measurement site, using the Wilcoxon test, some differences wer

Table I. Media and standart deviation values from Osstel ISQ.

\begin{tabular}{|c|c|c|c|c|c|c|c|c|}
\hline & \multicolumn{4}{|c|}{ External Hexagon } & \multicolumn{4}{|c|}{ Morse Taper } \\
\hline & Buccal & Mesial & Lingual & Distal & Buccal & Mesial & Lingual & Distal \\
\hline Implant & $75.7 \pm 4.5$ & $76.6 \pm 5.3$ & $76.3 \pm 4.5$ & $76.6 \pm 5.4$ & $75.1 \pm 4.7$ & $77.8 \pm 3.7$ & $77.0 \pm 4.2$ & $77.9 \pm 5.7$ \\
\hline Abutment & $72.0 \pm 5.7$ & $74.0 \pm 4.9$ & $71.9 \pm 6.0$ & $73.9 \pm 5.0$ & $71.9 \pm 5.7$ & $73.4 \pm 5.3$ & $72.0 \pm 5.3$ & $73.2 \pm 5.4$ \\
\hline
\end{tabular}


POZZER, L.; GABRIELLI, M. A. C.; TORRES NETO, R. A.; SPIN-NETO, R.; ASPRINO, L. \& PEREIRA-FILHO, V. A. Is there a difference in resonance frequency values obtained directly on the implants and abutments? Int. J. Odontostomat., 9(3):483-487, 2015.

\section{DISCUSSION}

A decrease in the resonance frequency values had been observed when implants were in the process of becoming loose (Meredith et al., 1997a). It was then claimed that failing implants might be identified by RFA and consequently managed appropriately. Failing implants tended to show a continuous decrease of implant stability quotient (ISQ) values until failure when measured with the Osstell device (Sennerby et al., 2000).

Animal studies have shown that ISQ values increase with time after implant placement. In one study (Meredith et al., 1997b), two threaded commercially pure titanium implants were placed in the right tibia of each of 10 rabbits and ISQ measurements obtained at regular intervals up to 168 days, after which the rabbits were sacrificed and subjected to histomorphometric analysis. There was a significant increase in ISQ values for the first 40 days of healing, after which there was little further change. The changes in ISQ values might be related to the increase in stiffness of an implant in the surrounding tissues occurring during the healing phase.

Studies looking for early healing in dogs showed that the osseointegration started during the first week after implant placement (Berglundh et al., 2003; Abrahamsson et al.). The bone tissue immediately lateral to the pitch region of the screw threads, responsible for primary mechanical stability of the implant, became resorbed in discrete areas after 1-2 weeks and replaced with newly formed bone. Despite the temporary loss of hard tissue contact, the implants remained clinically stable at all times. This indicated that during the first few weeks of healing, the mechanical anchorage of the implant was replaced by a biological attachment consisting of woven bone on the implant surface. Another study on 14 partially edentulous patients treated with 45 implants showed that implant stability levels after 1 year of loading were in the range of 57-82 ISQ units, with a mean of 69 (SD 6.5). However, no correlation was found between implant length and ISQ values (Balleri et al.). It has been speculated that higher ISQ values indicate greater implant stability and presumably more extensive osseointegration (Barewal et al., 2003).

Resonance frequency of the transducer/ implant system is calculated from the peak amplitude of the signal. Resonance frequency is determined by the stiffness of the bone-implant interface and by the distance from the transducer to the first bone- implant contact. Factors influencing RFA assessments have been recently identified. The bony structure of the parent bone into which the implant was installed was the most significant factor of variability, while implant length contributed to variability in a longitudinal comparison over time to a limited extent (Sim \& Lang).

Significantly higher ISQ values were identified in mandibular sites rather than for maxillary sites (ISQ 66 vs. 58) following implant placement and up to 6 months thereafter (Sennerby et al.). Also, ISQ values continuously and significantly increased for maxillary implants until there was no statistically significant difference between maxillary and mandibular implants after 6 months of loading. Other studies also showed that implants with low primary stability showed a greater increase in ISQ values up to abutment connection as compared with implants with very high primary stability. Moreover, a correlation between bone quality and primary implant stability was observed regardless of the implant site.

The Osstell ISQ device is used to determine resonance frequency values and is supposed to yield objective measurements of implant stability in ISQ values. These measurements may be done at implant placement, at any time during healing and after loading of the implants.

Hence, RFA is believed to be a potentially useful clinical instrument for the detection of implant tissue progressive failure. Because resonance frequency has been postulated to reflect the bone anchorage of the implant (Meredith et al., 1996, 1998), RFA may be applicable in the prevention, diagnosis and prediction of implant failures (Huang et al., 2003; Sjöström et al., 2005).

The Osstell device used in all those studies was relatively cumbersome to be mounted on the implants and was only designed for very few implant systems. Also, it was evident that standardization of the device positioning was of utmost importance (Aparicio et al.). Consequently, it has been shown that a linear relationship existed between the abutment height and ISQ values (Sennerby \& Meredith).

A novel generation of an electronically controlled RFA device was developed recently. This Osstell instrument is clinically much easier to handle, 
sterilizable and should fulfill all requirements for robust and reproducible assessments. However, studies with this device are still scarce. Also, the occlusal or the lateral positioning of the probe in relation to the peg did not affect the ISQ values, while buccolingual vs. mesiodistal directional assessments appear to be a source of slight variability (Park et al., 2010). Another difference was observed in this study as compared external hexagon implants and morse taper, there was a trend to higher ISQ values for morse taper implants when measurements were taken directly on the implants. But this is reversed when it performed the measurements of ISQ with abutments installed, HE implants showed higher ISQ values compared with morse taper implants with abutments installed. When evaluated separately external hexagon implants and morse taper implants, ISQ values obtained directly on the implants were higher than with the abutments installed.
Therefore, further studies are needed to investigate why this difference and if the morse taper implants abutments have some interference in obtaining frequency by Osstell ISQ.

\section{CONCLUSIONS}

In the long term, external hexagon and cone morse implants showed ISQ values compatible with successful osseointegration. The values for Morse taper implants were always higher in a statistically significant manner, when compared to the external hexagon. There is a difference related to the site of measurement, since the values found in the abutments were smaller.

POZZER, L.; GABRIELLI, M. A. C.; TORRES NETO, R. A.; SPIN-NETO, R.; ASPRINO, L. \& PEREIRA-FILHO, V. A. $¿$ Existe diferencia en la frecuencia de resonancia obtenida directamente en los implantes y pilares? Int. J. Odontostomat., 9(3):483-487, 2015.

RESUMEN: El objetivo fue evaluar las diferencias del coeficiente de estabilidad de implantes comparando los de conexión de hexágono externo (HE) y cono morse (CM). El estudio tuvo un diseño de boca dividida, siendo compuesta por 10 pacientes que recibieron protocolos protésicos de tipo hibrido. En total, 40 implantes $(3,75 \times 13 \mathrm{~mm})$ fueron instalados: en el lado derecho, 20 implantes de hexágono externo y en el lado izquierdo, 20 implantes de cono morse. Después de dos años en función, la prueba de estabilidad fue aplicada utilizando una maquina MRI, Ostell ISQ directamente sobre los implantes y pilares. Considerando las medidas en los implantes, hubo diferencias entre los implantes $\mathrm{HE}$ y $\mathrm{CM}$ en mesial $(p=0,011)$, lingual $(p=0,003)$ y distal $(p=0,006)$. Considerando las medidas en los pilares, hubo diferenciasentre HE y CM en el sector bucal $(p=0,020)$ y lingual $(p=0,004)$. Los valores mas altos se obtuvieron en $C M$; los valores de las conexión tipo cono morse presentaron mayor estabilidad al comparase con los implantes de conexión de hexágono externo.

PALABRAS CLAVE: estabilidad de implantes, coeficiente de estabilidad del implante, implante dental.

\section{REFERENCES}

Abrahamsson, I.; Berglundh, T.; Linder, E.; Lang, N.P. \& Lindhe, J. Early bone formation adjacent to rough and turned endosseous implant surfaces. An experimental study in the dog. Clin. Oral Implants Res., 15(4):381-92, 2004.

Adell, R.; Lekholm, U. \& Branemark, P. I. Surgical procedures. In: Branemark, P. I.; Zarb, G. A. \& Albrektsson, T. (Eds.). Tissue Integrated Prostheses. Osseointegration in Clinical Dentistry. Chicago, Quintessence Publishing, 1985. pp.211-32.

Aparicio, C.; Lang, N. P. \& Rangert, B. Validity and clinical significance of biomechanical testing of implant/bone interface. Clin. Oral Implants Res., 17 (Suppl. 2):2-7, 2006.
Balleri, P.; Cozzolino, A.; Ghelli, L.; Momicchioli, G. \& Varraile, A. Stability measurements of osseointegrated implants using Osstell in partially edentulous jaws after 1 year of loading: a pilot study. Clin. Implant Dent. Relat. Res., 4(3):128-32, 2002.

Berglundh, T.; Abrahamsson, I.; Lang, N. P. \& Lindhe, J. De novo alveolar bone formation adjacent to endosseous implants. Clin. Oral Implants Res., 14(3):251-62, 2003.

Brånemark, R.; Ohrnell, L. O.; Nilsson, P. \& Thomsen, P. Biomechanical characterization of osseointegration during healing: an experimental in vivo study in the rat. Biomaterials, 18(14):969-78, 1997. 
POZZER, L.; GABRIELLI, M. A. C.; TORRES NETO, R. A.; SPIN-NETO, R.; ASPRINO, L. \& PEREIRA-FILHO, V. A. Is there a difference in resonance frequency values obtained directly on the implants and abutments? Int. J. Odontostomat., 9(3):483-487, 2015.

Barewal, R. M.; Oates, T. W.; Meredith, N. \& Cochran, D. L. Resonance frequency measurement of implant stability in vivo on implants with a sandblasted and acid-etched surface. Int. J. Oral Maxillofac. Implants, 18(5):641-51, 2003.

Bischof, M.; Nedir, R.; Szmukler-Moncler, S.; Bernard, J. P. \& Samson, J. Implant stability measurement of delayed and immediately loaded implants during healing. Clin. Oral Implants Res., 15(5):529-39, 2004.

Friberg, B.; Sennerby, L.; Linden, B.; Grondahl, K. \& Lekholm, U. Stability measurements of one-stage Brånemark implants during healing in mandibles. A clinical resonance frequency analysis study. Int. J. Oral Maxillofac. Surg., 28(4):266-72, 1999a.

Friberg, B.; Sennerby, L.; Meredith, N. \& Lekholm, U. A comparison between cutting torque and resonance frequency measurements of maxillary implants. A20-month clinical study. Int. J. Oral Maxillofac. Surg., 28(4):297-303, 1999b.

Heo, S. J.; Sennerby, L.; Odersjö, M.; Granström, G.; Tjellström, A. \& Meredith, N. Stability measurements of craniofacial implants by means of resonance frequency analysis. A clinical pilot study. J. Laryngol. Otol., 112(6):537-42, 1998.

Huang, H. M.; Chiu, C. L.; Lin, C. T.; Lin, L. H. \& Lee, S. Y. Early detection of implant healing process using resonance frequency analysis. Clin. Oral Implants Res., 14(4):437-43, 2003.

Huwiler, M. A.; Pjetursson, B. E.; Bosshardt, D. D.; Salvi, G. E. \& Lang, N. P. Resonance frequency analysis in relation to jawbone characteristics and during early healing of implant installation. Clin. Oral Implants Res., 18(3):275-80, 2007.

Kessler-Liechti, G.; Zix, J. \& Mericske-Stern, R. Stability measurements of 1-stage implants in the edentulous mandible by means of resonance frequency analysis. Int. J. Oral Maxillofac. Implants, 23(2):353-8, 2008.

Meredith, N.; Alleyne, D. \& Cawley, P. Quantitative determination of the stability of the implant-tissue interface using resonance frequency analysis. Clin. Oral Implants Res., 7(3):261-7, 1996.

Meredith, N.; Book, K.; Friberg, B.; Jemt, T. \& Sennerby, L. Resonance frequency measurements of implant stability in vivo. A cross-sectional and longitudinal study of resonance frequency measurements on implants in the edentulous and partially dentate maxilla. Clin. Oral Implants Res., 8(3):226-33, 1997a.

Meredith, N.; Shagaldi, F.; Alleyne, D.; Sennerby, L. \& Cawley, $P$. The application of resonance frequency measurements to study the stability of titanium implants during healing in the rabbit tibia. Clin. Oral Implants Res., 8(3):234-43, 1997b.
Park, J. C.; Kim, H. D.; Kim, S. M.; Kim, M. J. \& Lee, J. H. A comparison of implant stability quotients measured using magnetic resonance frequency analysis from two directions: a prospective clinical study during the initial healing period. Clin. Oral Implants Res., 21(6):591-7, 2010.

Rasmusson, L.; Meredith, N.; Kahnberg, K. E. \& Sennerby, L. Stability assessments and histology of titanium implants placed simultaneously with autogenous onlay bone in the rabbit tibia. Int. J. Oral Maxillofac. Surg., 27(3):229-35, 1998.

Rasmusson, L.; Meredith, N.; Kahnberg, K. E. \& Sennerby, L. Effects of barrier membranes on bone resorption and implant stability in onlay bone grafts. An experimental study. Clin. Oral Implants Res., 10(4):267-77, 1999.

Rasmusson, L.; Kahnberg, K. E. \& Tan, A. Effects of implant design and surface on bone regeneration and implant stability: an experimental study in the dog mandible. Clin. Implant Dent. Related Res., 3(1):2-8, 2001.

Schroeder, A.; Pohler, O. \& Sutter, F. Geweberektion auf eeine TitanSpritzchichtoberfläche. Schweiz. Monatsschr. Zahnmed, 86:713-27, 1976.

Sim, C. P. C. \& Lang, N. P. Factors influencing resonance frequency analysis assessed by Osstell mentor during implant tissue integration: I. Instrument positioning, bone structure, implant length. Clin. Oral Implants Res., 21(6):598-604, 2010.

Sjöström, M.; Lundgren, S.; Nilson, H. \& Sennerby, L. Monitoring of implant stability in grafted bone using resonance frequency analysis. A clinical study from implant placement to 6 months of loading. Int. J. Oral Maxillofac. Surg., 34(1):45-51, 2005.

Sennerby, L.; Friberg, B.; Linden, B.; Jemt, T. \& Meredith, N. A comparison of implant stability in mandibular and maxillary bone using RFA. Abstract. Gothenburg, Resonance Frequency Analysis Symposium, 2000.

Sennerby, L. \& Meredith, N. Resonance frequency analysis: measuring implant stability and osseointegration. Compend. Contin. Educ. Dent., 19(5):493-8, 500, 502, 1998.

\section{Correspondence to:}

Dr. Leandro Pozzer

Division of Oral and Maxillofacial Surgery

State University of Campinas

BRAZIL

Received: 08-08-2015

Email: leandropozzer@yahoo.com.br Accepted: 11-12-2015 leandrosouzapozzer@gmail.com 